\title{
Synthesis of a Lewis Base Stabilized Dimer of N-Substituted Hydrosila Hydrazone and a Silaaziridine
}

\author{
Sankaranarayana Pillai Sarish,${ }^{\dagger}$ Anukul Jana ${ }^{\dagger}$ Herbert W. Roesky, ${ }^{*}{ }^{\dagger}$ Prinson P. Samuel,${ }^{\dagger}$ \\ Carlos E. Abad Andrade, ${ }^{\dagger}$ Birger Dittrich, ${ }^{\dagger}$ and Carola Schulzke ${ }^{\S}$ \\ ${ }^{\dagger}$ Institut für Anorganische Chemie, Universität Göttingen, Tammannstrasse 4, 37077 Göttingen, \\ Germany, and ${ }^{\S}$ School of Chemistry, Trinity College Dublin, Dublin 2, Ireland
}

Received November 12, 2010

\begin{abstract}
The dehydrohalogenation of a silicon(IV)-substituted diphenyl hydrazone derivative leads to a dimer of a N-substituted hydrosila hydrazone, which consists of a four-membered $\mathrm{Si}_{2} \mathrm{~N}_{2}$ core and a hydrogen attached to each of the silicon atoms instead of giving a substituted hydrosilaneimine. The compound is obviously formed by dimerization of hydrosilaneimine. Moreover there are no straightforward synthetic methods known for the synthesis of silaaziridine. The preparation of such species would be of special importance for the development of a new field of silicon chemistry. The reaction of chlorosilylene, $\mathrm{LSiCl}$, and $\mathrm{PhCH}=\mathrm{NPh}$ resulted in a base-stabilized silaaziridine. All compounds were characterized by NMR spectroscopy, mass spectrometry, microanalysis, and X-ray structural analysis.
\end{abstract}

\section{Introduction}

The stable allotropes of the lighter $\mathrm{p}$ block elements such as nitrogen and oxygen possess triple and double bonds, respectively. Nitrogen has a ubiquitous nature to form double as well as triple bonds with carbon. Silicon, the congener of carbon, forms silane imine complexes, ${ }^{1-3}$ which constitute a vital area of research in the last two decades. However stable hydrosilaneimines, compounds with a $\mathrm{Si}=\mathrm{N}$ double bond and one hydrogen attached to the silicon atom, are elusive and have been characterized only in an argon matrix. ${ }^{4,5}$ Moreover examples of silaaziridines, which are constituted of three-membered $\mathrm{Si}-\mathrm{N}-\mathrm{C}$ ring systems, are scant. The paucity of such compounds is largely related to their limited synthetic approach. In the case of silaaziridines, Brook et al. reported for the first time their synthesis using isocyanides and photochemically generated silenes. ${ }^{6}$ However, this method lacks generality. Moreover, silaaziridines have been proposed as reactive intermediates in thermal and photochemical silylene transfer reactions to imines, although the strained three-membered ring compounds were not isolated,

*To whom correspondence should be addressed. E-mail: hroesky@ gwdg.de.

(1) Hesse, M.; Klingebiel, U. Angew. Chem. 1986, 98, 638-639. Angew. Chem., Int. Ed. Engl. 1986, 25, 649-650.

(2) Denk, M.; Hayashi, R. K.; West, R. J. Am. Chem. Soc. 1994, 116, 10813-10814.

(3) Wiberg, N.; Schurz, G.; Reber, G.; Müller, G. J. Chem. Soc., Chem. Commun 1986, 591-592.

(4) Maier, G.; Glatthaar, J. Angew. Chem. 1994, 106, 486-488. Angew. Chem., Int. Ed. Engl. 1994, 33, 473-475.

(5) Kuhn, A.; Sander, W. Organometallics 1998, 17, 4776-4783.

(6) Brook, A. G.; Kong, Y. K.; Saxena, A. K.; Sawyer, J. F. Organometallics 1988, 7, 2245-2247.

(7) Weidenbruch, M.; Piel, H. Organometallics 1993, 20, 2881-2882.

(8) Belzner, J.; Ihmels, H.; Pauletto, L.; Noltemeyer, M. J. Org. Chem. 1996, 61, 3315-3319. and instead rearranged products were obtained. ${ }^{7-9}$ In 2007 Woerpel et al. reported the synthesis of silaaziridine by applying silver triflate catalyzed silylene transfer from silacyclopropane to imines. ${ }^{10}$ The aziridines are used as precursors for the synthesis of $\mathrm{N}$-containing heterocyclic compounds, which are important for producing drugs ${ }^{11}$ and natural products. ${ }^{12}$ Stable silaaziridine could be an alternative precursor for the synthesis of N,Si-containing heterocyclic compounds. Subsequently a facile synthesis of stable hydrosilaneimines and silaaziridines would be a real challenge for the synthetic chemist. Recently we were successful in isolating the previously reported stable chlorosilylene $\mathrm{LSiCl}(\mathbf{1})\left(\mathrm{L}=\mathrm{PhC}(\mathrm{N} t \mathrm{Bu})_{2}\right)^{13}$ in high yield using $\mathrm{LiN}\left(\mathrm{SiMe}_{3}\right)_{2}$ as a dehydrohalogenating agent, ${ }^{14}$ which helped to carry out its versatile reactivities. Among them, one is the convenient synthesis of monosilaepoxide, which was formed by the reaction of $\mathbf{1}$ with ketones. ${ }^{15}$ The successful stabilization of monosilaoxirane by the benzamidinato ligand prompted us to probe the reaction of $\mathbf{1}$ with the $>\mathrm{C}=\mathrm{NR}$ precursor. The question arises whether it will afford [1+2] cycloaddition compounds or oxidative addition products.

(9) Gehrhus, B.; Hitchcock, P. B.; Lappert, M. F. Organometallics 1998, 17, 1378-1382.

(10) Nevárez, Z.; Woerpel, K. A. Org. Lett. 2007, 9, 3773-3776.

(11) Dahanukar, V. H.; Zavialov, L. A. Curr. Opin. Drug Discovery Dev. 2002, 5, 918-927.

(12) Kametani, T.; Honda, T. Adv. Heteroat. Chem. 1986, 39, $181-236$.

(13) So, C.-W.; Roesky, H. W.; Magull, J.; Oswald, R. B. Angew. Chem. 2006, 118, 4052-4054. Angew. Chem., Int. Ed. 2006, 45, $3948-3950$

(14) Sen, S. S.; Roesky, H. W.; Stern, D.; Henn, J.; Stalke, D. J. Am. Chem. Soc. 2010, 132, 1123-1126.

(15) Ghadwal, R. S.; Sen, S. S.; Roesky, H. W.; Granitzka, M.; Kratzert, D.; Merkel, S.; Stalke, D. Angew. Chem. 2010, 122, 40444077. Angew. Chem., Int. Ed. 2010, 49, 3952-3955. 
Scheme 1. Preparation of Silicon(IV)-Substituted Diphenyl Hydrazone (2), N-Substituted Hydrosila Hydrazone (3), and Silaaziridine (4)
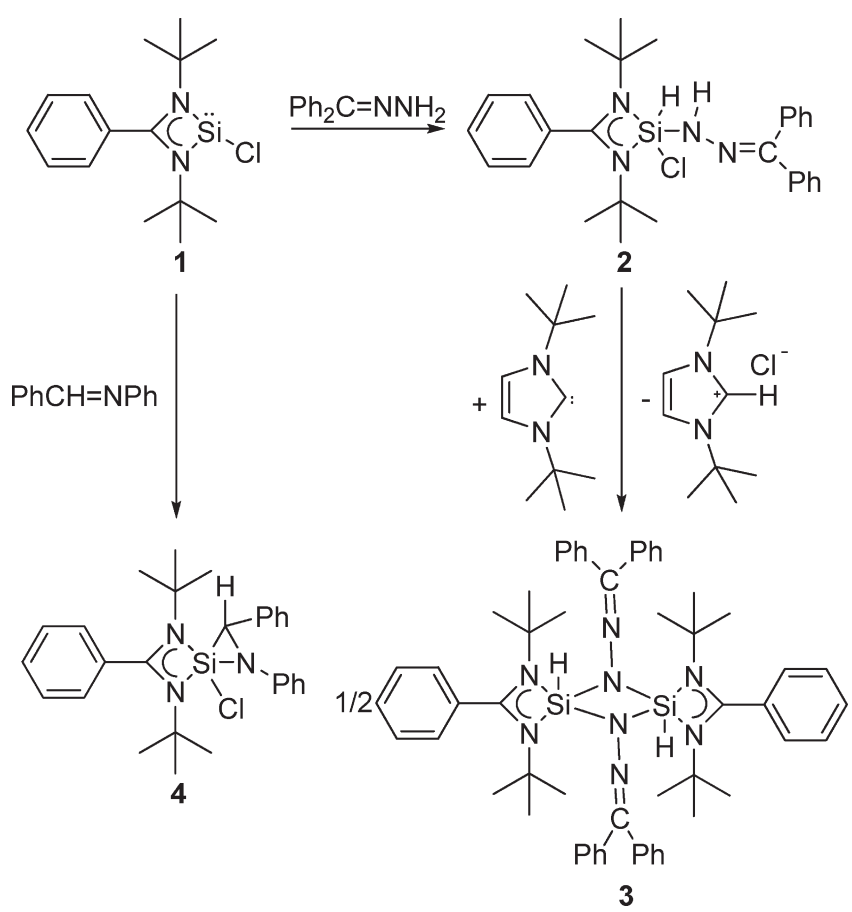

Herein, we report on the synthesis of a stable base-stabilized $\mathrm{Si}_{2} \mathrm{~N}_{2}$ core $\left[\mathrm{LSi}(\mathrm{H})-\mathrm{N}-\mathrm{N}=\mathrm{CPh}_{2}\right]_{2}\left(\mathrm{~L}=\mathrm{PhC}(\mathrm{N} t \mathrm{Bu})_{2}\right)$ (3) from the reaction of $\mathrm{LSiCl}(\mathrm{H}) \mathrm{N}(\mathrm{H})-\mathrm{N}=\mathrm{CPh}_{2}$ (2) with 1,3-bis(tert-butyl)imidazol-2-ylidene under $\mathrm{HCl}$ elimination. Here it is worth mentioning that compound $\mathbf{2}$ is obtained from the unprecedented oxidative addition of one of the $\mathrm{N}-\mathrm{H}$ bonds of diphenyl hydrazone $\left(\mathrm{Ph}_{2} \mathrm{C}=\mathrm{N}-\mathrm{NH}_{2}\right)$ to the silicon(II) center of the base-stabilized chlorosilylene, LSiCl (1). Furthermore an efficient method is outlined for the synthesis of stable silaaziridine $\mathbf{4}$ by the reaction of $\mathbf{1}$ with $\mathrm{N}$-benzylideneaniline $(\mathrm{PhCH}=\mathrm{NPh})$.

\section{Results and Discussion}

The reaction of chlorosilylene, $\mathrm{LSiCl}(\mathbf{1})$, with diphenyl hydrazone in toluene leads to the silicon(IV)-substituted diphenyl hydrazone derivative $\operatorname{LSiCl}(\mathrm{H}) \mathrm{N}(\mathrm{H})-\mathrm{N}=\mathrm{CPh}_{2}$ (2) (Scheme 1). The reaction proceeds via the oxidative addition of one of the $\mathrm{N}-\mathrm{H}$ bonds to the silicon(II) center. A similar reaction was observed when ammonia was reacted with the silylene $\mathrm{L}^{\prime} \mathrm{Si}\left(\mathrm{L}^{\prime}=\mathrm{CH}\left\{\left(\mathrm{C}=\mathrm{CH}_{2}\right)(\mathrm{CMe})\left(2,6-i \mathrm{Pr}_{2} \mathrm{C}_{6} \mathrm{H}_{3} \mathrm{~N}\right)_{2}\right\}\right) .{ }^{16}$ In contrast to the present results, when $\mathrm{L}^{\prime} \mathrm{Si}$ was reacted with diphenyl hydrazone, there was exclusive formation of the $[1+4]$ cycloaddtion product. ${ }^{17}$ The different reactivity is mainly due to the difference in coordination numbers around the silicon atom of the two silylenes.

The formation of compound $\mathbf{2}$ was confirmed by elemental analysis, multinuclear NMR spectroscopy, and EI mass spectrometry. The ${ }^{1} \mathrm{H}$ NMR spectrum of $\mathbf{2}$ shows resonances at $\delta 6.48$ and $6.62 \mathrm{ppm}$ for the $\mathrm{Si}-\mathrm{H}$ and $\mathrm{N}-\mathrm{H}$ proton, respectively, and both exhibit doublets with the same coupling constant $\left({ }^{3} J=3 \mathrm{~Hz}\right)$. The ${ }^{29} \mathrm{Si}$ NMR spectrum exhibits a

(16) Jana, A.; Schulzke, C.; Roesky, H. W. J. Am. Chem. Soc. 2009, $131,4600-4601$.

(17) Jana, A.; Schulzke, C.; Roesky, H. W.; Samuel, P. P. Organometallics 2009, 28, 6574-6577.

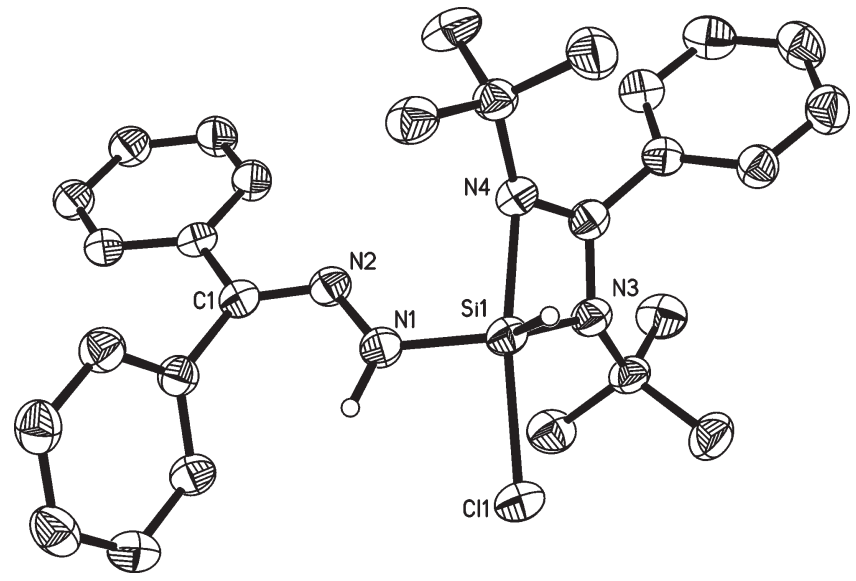

Figure 1. Molecular structure of 2. Thermal ellipsoids are shown at $50 \%$ probability. $\mathrm{H}$ atoms except on Sil and $\mathrm{N} 1$ are omitted for clarity reasons. Selected bond distances $(\AA)$ and angles (deg): Si1-Cl1 2.2045(13), Si1-N1 1.722(3), N1-N2 1.364(3), Si1-N3 1.802(3); N2-N1-Si1 124.3(2), N1-Si1-Cl1 $90.23(10)$.

doublet of doublets at $\delta-99.82 \mathrm{ppm}\left({ }^{1} J\left({ }^{29} \mathrm{Si}-{ }^{1} \mathrm{H}\right)=\right.$ $\left.299.45 \mathrm{~Hz},{ }^{2} J\left({ }^{29} \mathrm{Si}-{ }^{1} \mathrm{H}\right)=10.78 \mathrm{~Hz}\right)$. Furthermore the solidstate structure of compound $\mathbf{2}$ was confirmed by single-crystal $\mathrm{X}$-ray structural analysis.

Single crystals of $\mathbf{2}$ were obtained from a hot saturated $n$-hexane solution at room temperature after one day. Compound 2 crystallizes in the triclinic space group $P \overline{1}$, with one monomer in the asymmetric unit as illustrated in Figure 1. Surprisingly, $\mathbf{2}$ is monomeric in the solid state, and what is even more striking, the NH group is not involved in any kind of hydrogen bonding. Compound $\mathbf{2}$ is stable in the solid state as well as in solution for a longer period of time without any decomposition under an inert atmosphere. The coordination polyhedron around the silicon atom features a distorted tetragonal-pyramidal geometry. The silicon is attached to two nitrogen atoms from the backbone of the chelating ligand, the nitrogen atom from the diphenyl hydrazone moiety, the $\mathrm{Cl}$ atom, and a hydrogen atom. The $\mathrm{N} 1-\mathrm{N} 2$ bond length is 1.364(3) $\AA$, which is indicative of a $\mathrm{N}-\mathrm{N}$ single bond. A noteworthy feature of compound 2 is the $\mathrm{Si}(\mathrm{H}) \mathrm{NH}$ moiety (Si1-N1 1.722(3) $\mathrm{A})$. The $\mathrm{Si}-\mathrm{N} 1$ bond length can be compared with the slightly shorter $\mathrm{Si}-\mathrm{N}$ bond lengths than that in $\mathrm{RSi}\left(\mathrm{NH}_{2}\right)_{3}$ $\left(\mathrm{R}=2,4,6-\mathrm{Ph}_{3} \mathrm{C}_{6} \mathrm{H}_{2}\right.$ av $1.709(7) \AA{ }^{18},{ }^{18} \mathrm{R}=2,6-i \mathrm{Pr}_{2} \mathrm{C}_{6} \mathrm{H}_{3}$ $\mathrm{NSiMe}_{3}$ av 1.709(2) $\AA$, ${ }^{19}$ and $\mathrm{R}=2,4,6-t \mathrm{BuC}_{6} \mathrm{H}_{2} \mathrm{O}$ av $1.692(6) \AA) .{ }^{19}$

Compound 2 exhibits a $\mathrm{Si}-\mathrm{H}$ as well as a $\mathrm{N}-\mathrm{H}$ bond, which both are potential proton donors for the elimination of $\mathrm{HCl}$. This would occur from either the 1,1 or 1,2 position while adding a proton scavenger (such as amine, N-heterocyclic carbene). In the case of $1,1 \mathrm{HCl}$ elimination there would be the formation of $\mathrm{LSiN}(\mathrm{H}) \mathrm{N}=\mathrm{CPh}_{2}$, while $1,2 \mathrm{HCl}$ elimination would lead to the substituted hydrosilaneimine derivative $\mathrm{LSi}(\mathrm{H})=\mathrm{NNCPh}_{2}$. In the literature there are protocols on both the formation of silylene compounds by

(18) Ruhlandt-Senge, K.; Bartlett, R. A.; Olmstead, M. M.; Power, P. P. Angew. Chem. 1993, 105, 459-461. Angew. Chem., Int. Ed. Engl. 1993, 32, 425-427.

(19) Wraage, K.; Künzel, A.; Noltemeyer, M.; Schmidt, H.-G.; Roesky, H. W. Angew. Chem. 1995, 107, 2954-2956. Angew. Chem., Int. Ed. Engl. 1995, 34, 2645-2647. 


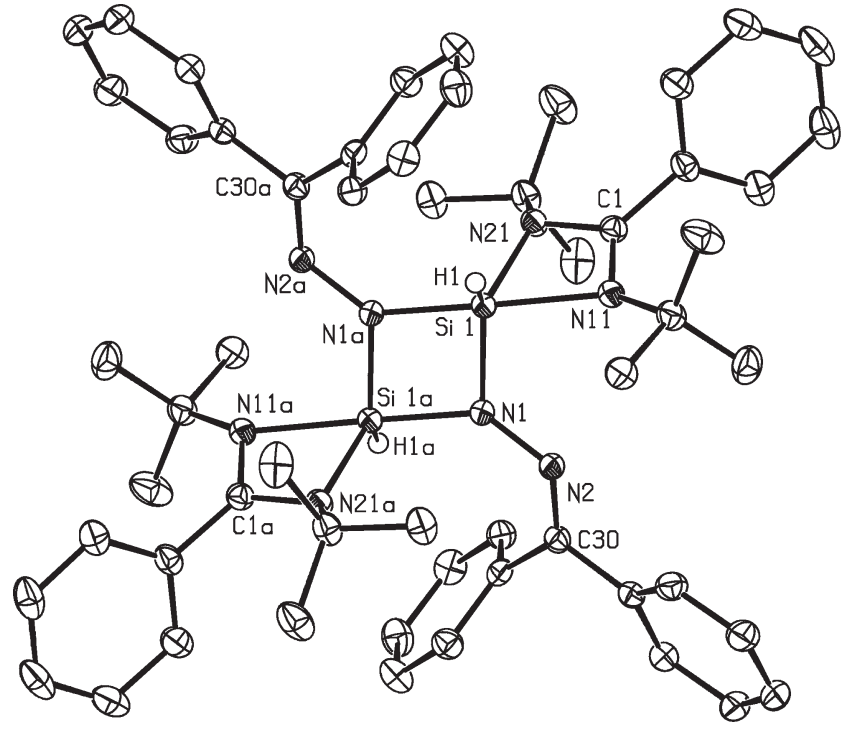

Figure 2. Molecular structure of 3. Thermal ellipsoids are shown at $50 \%$ probability. $\mathrm{H}$ atoms except on those on silicon are omitted for clarity reasons. Selected bond lengths [̊] and angles [deg]: Si1-N11 2.0280(11), Si1-N21 1.8306(10), Sil-N1 1.7521(10), Si1-H 1.350; N11-Si1-N21 68.18(4), N11-Si1-N1 99.17(5), Si1-N1-Si1a 99.66(5).

$1,1 \mathrm{HCl}$ elimination ${ }^{20,21}$ and the formation of compounds with $\mathrm{Si}=\mathrm{N}$ bonds by $1,2 \mathrm{HCl}$ elimination. ${ }^{22}$ The reaction of compound $\mathbf{2}$ with an equivalent amount of 1,3-bis(tert-butyl)imidazol-2-ylidene ${ }^{23}$ leads only to $\mathrm{N}$-substituted hydrosila hydrazone as a dimer of composition [LSi(H)$\left.\mathrm{NN}=\mathrm{CPh}_{2}\right]_{2}(3)$ in good yield (Scheme 1) instead of forming the hydrosilaneimine derivative $\mathrm{LSi}(\mathrm{H})=\mathrm{NNCPh}_{2}$. This is in contrast to the reaction of $\mathrm{LSiHCl}_{2}$ with the same carbene, ${ }^{14}$ which yields exclusively $\mathrm{LSiCl}$.

3 is a yellow solid soluble in benzene, toluene, diethyl ether, and THF, respectively, and shows no decomposition on exposure to dry air. 3 was characterized by multinuclear spectroscopy, EI mass spectrometry, elemental analysis, and X-ray structural analysis. The ${ }^{1} \mathrm{H}$ NMR spectrum of 3 exhibits a singlet ( $\delta 4.86 \mathrm{ppm})$ that can be assigned to the $\mathrm{Si}-\mathrm{H}$ proton, accompanied by two ${ }^{29} \mathrm{Si}$ satellite resonances. The ${ }^{29} \mathrm{Si}$ NMR spectrum exhibits a doublet resonance $(\delta-96.65 \mathrm{ppm})$ with a coupling constant of $J\left({ }^{29} \mathrm{Si}-\mathrm{H}\right)=$ $286.18 \mathrm{~Hz}$. Suitable crystals for X-ray structural analysis were obtained from a hot saturated THF solution of 3 after storing this solution overnight at room temperature. 3 crystallizes in the monoclinic space group $P 2_{1} / n$, with one-half molecule of $\mathbf{3}$ in the asymmetric unit and one slightly disordered THF molecule. 3 exists as a dimer in the solid state (Figure 2). There are no classical intermolecular hydrogen bonds observed in the crystal lattice. Geometry criteria suggest one attractive $\mathrm{C}-\mathrm{H} \cdot \mathrm{H} \cdot \mathrm{N}$ hydrogen bond

(20) Ghadwal, R. S.; Roesky, H. W.; Merkel, S.; Henn, J.; Stalke, D. Angew. Chem. 2009, 121, 5793-5796. Angew. Chem., Int. Ed. 2009, 48, $5683-5686$.

(21) Filippou, A. C.; Chernov, O.; Blom, B.; Stumpf, K. W.; Schnakenburg, G. Chem.-Eur. J. 2010, 16, 2866-2872.

(22) Li, B.; Matsuo, T.; Hashizume, D.; Fueno, H.; Tanaka, K.; Tamao, K. J. Am. Chem. Soc. 2009, 131,13222-13223.

(23) (a) Arduengo, A. J.; Bock, H.; Chen, H.; De, M.; Dixon, D. A.; Green, J. C.; Herrmann, W. A.; Jones, N. L.; Wagner, M.; West, R. J. Am. Chem. Soc. 1994, 116, 6641-6649. (b) Scott, N. M.; Dorta, R.; Stevens, E. D.; Correa, A.; Cavallo, L.; Nolan, S. P. J. Am. Chem. Soc. 2005, $127,3516-3526$. each. The coordination polyhedron around the silicon atom comprises two nitrogen atoms from the supporting ligand, one hydrogen atom, and two nitrogen atoms of the hydrazone moiety, featuring a distorted trigonalbipyramidal geometry. The axial positions are occupied by two nitrogen atoms. The axial substituents include an angle of $80.34^{\circ}$ with the silicon atom. The distorted trigonal-bipyramidal architecture includes different $\mathrm{Si}-\mathrm{N}$ bond distances for axial and equatorial substituents. The $\mathrm{Si}-\mathrm{N}$ bond lengths in the equatorial positions ( $\mathrm{Si} 1-\mathrm{N} 1$ $1.752 \AA$ and $\mathrm{Si} 1-\mathrm{N} 211.831 \AA$ ) are shorter than that in the axial positions ( $\mathrm{Si}-\mathrm{N} 112.028 \AA$ ). In summary, compound 3 represents a stable crystalline compound with three fourmembered rings that are connected through silicon atoms, and it exhibits at each silicon center a terminal-bound hydrogen atom.

After the successful synthesis of an N-substituted hydrosila hydrazone, we turned our attention to the synthesis of silaaziridine. From the retrosynthetic point of view, the silaaziridines can be prepared by reacting either silene with nitrene or, alternatively, silaimine with carbene, or imine with silylene. The preparation of stable silene ${ }^{24-26}$ and silaimine $e^{1-3}$ is limited, although nowadays there are numerous reports on stable silylenes. ${ }^{27,28}$ For developing a new route to stable silaaziridines we employed the reaction of stable silylenes with imines. Finally it is noteworthy that in all the known silaaziridines the silicon atom binds to either carbon or silicon. So far no compounds are available where heteroatoms are attached to silicon.

The addition of $\mathrm{N}$-benzylideneaniline $(\mathrm{PhCH}=\mathrm{NPh})$ to a solution of $\mathbf{1}$ in toluene leads to compound $\mathbf{4}$ (Scheme 1). The colorless solution was evaporated, and the residue extracted with hot $n$-hexane to yield colorless crystals of $\mathbf{4}$ in $88 \%$ yield. The exact mechanism for the formation of $\mathbf{4}$ is unknown, but two mechanistic pathways can be envisioned. Either an electrophilic attack of $\mathbf{1}$ could occur at the imine nitrogen of $N$-benzylideneaniline to give a sila ylide, or alternatively, a nucleophilic attack of $\mathbf{1}$ to the imine carbon of $N$-benzylideneaniline might be possible to result in a charge-separated species. Both pathways can lead to compound $\mathbf{4}$ after successive ring closure. Compound $\mathbf{4}$ is well soluble in benzene, toluene, THF, and diethyl ether and shows no decomposition on exposure to dry air. 4 was characterized by ${ }^{1} \mathrm{H}$ and ${ }^{29} \mathrm{Si}$ NMR spectroscopy, EI mass spectrometry, elemental analysis, and $\mathrm{X}$-ray structural analysis.

The ${ }^{1} \mathrm{H}$ NMR spectrum of 4 exhibits a singlet resonance ( $\delta 4.07 \mathrm{ppm}$ ) that can be assigned to the $\mathrm{C}-H$ proton of the three-membered silaaziridine ring. The ${ }^{29} \mathrm{Si}$ NMR spectrum exhibits a singlet resonance $(\delta-131.35 \mathrm{ppm})$ consistent with a neutral pentacoordinate silicon. ${ }^{26}$ Single crystals of 4 were obtained from a saturated hot $n$-hexane solution after one day. Compound $\mathbf{4}$ crystallizes in the triclinic space group $P \overline{1}$, with two molecules in the asymmetric unit. Interestingly, the

(24) Ishikawa, M.; Kikuchi, M.; Watanabe, K.; Sakamoto, H.; Kunai J. Organomet. Chem. 1993, 443, C3-C5.

(25) Bravo-Zhivotovskii, D.; Dobrovetsky, R.; Nemirovsky, D.; Molev, V.; Bendikov, M.; Molev, G.; Botoshansky, M.; Apeloig, Y. Angew. Chem. 2008, 120, 4415-4417. Angew. Chem., Int. Ed. 2008, 47, 4343-4345.

(26) Corriu, R.; Lanneau, G.; Priou, C. Angew. Chem. 1991, 103, 1153-1155. Angew. Chem., Int. Ed. Engl. 1991, 30, 1130-1132.

(27) So, C.-W.; Roesky, H. W.; Gurubasavaraj, P. M.; Oswald, R. B.; Gamer, M. T.; Jones, P. G.; Blaurock, S. J. Am. Chem. Soc. 2007, 129, 12049-12054.

(28) Filippou, A. C.; Chernov, O.; Schnakenburg, G. Angew. Chem. 2009, 121, 5797-5800. Angew. Chem., Int. Ed. 2009, 48, 5687-5690. 


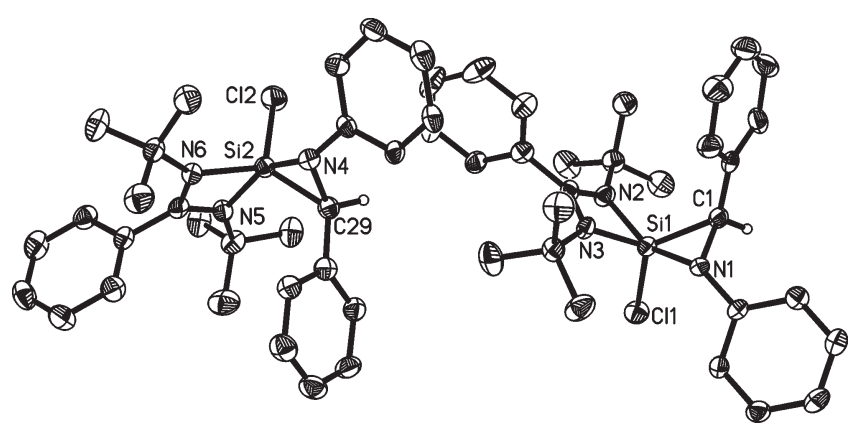

Figure 3. Molecular structure of $\mathbf{4}$ shows the two different isomers in the asymmetric unit. Thermal ellipsoids are shown at $50 \%$ probability. $\mathrm{H}$ atoms except on $\mathrm{C} 1$ and $\mathrm{C} 29$ are omitted for clarity reasons. Selected bond lengths $[\AA]$ and angles [deg]: Sil-Cl1 2.0800(17), Sil-N1 1.733(4), Sil-C1 1.858(4), SilN2 1.914(4); N1-Si1-C1 49.58(16), N1-Si1-Cl1 105.35(13), N2-Si1-N3 70.89(15).

unit cell contains two different isomers. C1 and C29 exhibit chirality that is distinct in the two cases. The hydrogens at these carbon atoms were found and refined freely with respect to the location but constrained with respect to the displacement parameters. X-ray crystal structure analysis afforded the structure as illustrated in Figure 3. Compound 4 is stable in the solid state as well as in solution for a longer period of time without any decomposition under inert atmosphere. The coordination polyhedron around the silicon atom features a distorted trigonal-bipyramidal geometry, with the chlorine atom at an axial position. The silicon is attached to two nitrogen atoms from the backbone of the chelating ligand, one carbon and one nitrogen atom from the imine moiety, and a chlorine atom. The three nitrogen atoms are in equatorial positions, whereas the carbon is in between an equatorial and axial position, giving rise to the distortion. The composition of $\mathbf{4}$ was also confirmed by mass spectrometry and elemental $(\mathrm{C}, \mathrm{H}, \mathrm{N})$ analysis. The most intense peak in the EI mass spectrum appeared at $m / z=475[\mathrm{M}]^{+}$.

\section{Conclusions}

In summary, we have demonstrated that base-stabilized chlorosilylene, $\mathrm{LSiCl}$, allows for a convenient oxidative addition reaction of one of the $\mathrm{N}-\mathrm{H}$ bonds of phenyl hydrazone under the formation of a silicon(IV)-substituted hydrazone derivative. The latter undergoes a 1,2 $\mathrm{HCl}$ elimination by a $\mathrm{N}$-heterocyclic carbene to generate a stable $\mathrm{N}$-substituted hydrosila hydrazone as a dimer that contains a chain of three four-membered rings, and in the spirocyclic structure each $\mathrm{Si}$ atom is part of two four-membered rings and a hydrogen atom on silicon. Moreover we have shown a convenient method for an efficient synthesis of a stable silicon-heteroatom (chlorine, nitrogen) bound silaaziridine. The latter is prone to further functionalization and might have a similar impact on organic chemistry to that realized for carbon-heteroatom-bound aziridines. ${ }^{29}$

\section{Experimental Section}

General Procedures. All manipulations were performed under a dry and oxygen-free atmosphere $\left(\mathrm{N}_{2}\right)$ using standard Schlenk

(29) Singh, G. S.; D'hooghe, M.; Kimpe, N. D. Chem. Rev. 2007, 107, 2080-2135. techniques or inside a MBraun MB 150-GI glovebox maintained at or below $1 \mathrm{ppm}$ of $\mathrm{O}_{2}$ and $\mathrm{H}_{2} \mathrm{O}$. All solvents were distilled from $\mathrm{Na}$ /benzophenone prior to use. The starting material 1 was prepared using a literature procedure. ${ }^{14}$ Other chemicals were purchased and used as received. ${ }^{1} \mathrm{H},{ }^{13} \mathrm{C}$, and ${ }^{29} \mathrm{Si}$ NMR spectra were recorded on a Bruker Avance DRX instrument and referenced to the deuterated solvent in the case of the ${ }^{1} \mathrm{H}$ and ${ }^{13} \mathrm{C}$ NMR and $\mathrm{SiMe}_{4}$ for the ${ }^{29} \mathrm{Si}$ NMR spectra. Elemental analyses were performed by the Analytisches Labor des Instituts für Anorganische Chemie der Universität Göttingen. EI-MS were measured on a Finnigan Mat 8230 or a Varian MAT CH5 instrument. Melting points were measured in sealed glass tubes with a Büchi melting point B 540 instrument.

Synthesis of 2. A solution of $\mathrm{Ph}_{2} \mathrm{C}=\mathrm{NNH}_{2}(0.19 \mathrm{~g}, 1 \mathrm{mmol})$ in toluene $(10 \mathrm{~mL})$ was added to a toluene solution $(35 \mathrm{~mL})$ of $\mathbf{1}$ $(0.29 \mathrm{~g}, 1 \mathrm{mmol})$ at $-78^{\circ} \mathrm{C}$. The reaction mixture was allowed to warm slowly to room temperature and stirred for $12 \mathrm{~h}$ at this temperature. After that all volatiles were removed under vacuum. The residue was dissolved in $n$-hexane $(45 \mathrm{~mL})$, and the solution was warmed and filtered over a Celite pad. The resulting solution was kept overnight at room temperature to afford colorless crystals of 2 . Yield: $0.39 \mathrm{~g}, 80 \%$. Mp: $138-140{ }^{\circ} \mathrm{C} .{ }^{1} \mathrm{H}$ NMR $\left(500 \mathrm{MHz}, \mathrm{C}_{6} \mathrm{D}_{6}\right): \delta 7.85-7.84,7.18-6.84(\mathrm{~m}, 15 \mathrm{H}$, $\left.\mathrm{C}_{6} H_{5}\right), 6.62(\mathrm{~d}, 1 \mathrm{H}, \mathrm{NH}), 6.48(\mathrm{~d}, 1 \mathrm{H}, \mathrm{SiH}), 1.15(\mathrm{~s}, 18 \mathrm{H}$, $\left.\mathrm{C}\left(\mathrm{CH}_{3}\right)_{3}\right) \mathrm{ppm} .{ }^{13} \mathrm{C} \mathrm{NMR}\left(125 \mathrm{MHz}, \mathrm{C}_{6} \mathrm{D}_{6}\right): \delta 172.08,147.08$, $140.00,134.78,129.87,129.67,129.63,128.84,128.69,128.31$, $127.72,127.01,54.68,31.67 \mathrm{ppm} .{ }^{29} \mathrm{Si}$ NMR $(99.35 \mathrm{MHz}$, $\left.\mathrm{C}_{6} \mathrm{D}_{6}\right): \delta-99.82 \mathrm{ppm}\left(\mathrm{dd}, J=299.45\right.$ and $\left.{ }^{2} J=10.78 \mathrm{~Hz}\right)$. EI-MS (70 eV) $m / z(\%): 453(100 \%)[\mathrm{M}-2 \mathrm{H}-\mathrm{Cl}]^{+}, 489(10 \%)$ $[\mathrm{M}-\mathrm{H}]^{+}$. Anal. Calcd for $\mathrm{C}_{28} \mathrm{H}_{35} \mathrm{ClN}_{4} \mathrm{Si}: \mathrm{C}, 68.47 ; \mathrm{H}, 7.18 ; \mathrm{N}$, 11.41. Found: C, 68.47; H, 7.35; N, 11.46.

Synthesis of 3. A solution of 1,3-bis(tert-butyl)imidazol2-ylidene $(0.18 \mathrm{~g}, 1 \mathrm{mmol})$ in THF $(20 \mathrm{~mL})$ was added to a THF solution $(30 \mathrm{~mL})$ of $2(0.49 \mathrm{~g}, 1 \mathrm{mmol})$ at $-78^{\circ} \mathrm{C}$. The reaction mixture was allowed to warm gradually to room temperature and stirred overnight. After that all volatiles were removed under vacuum. The residue was dissolved in $n$-hexane $(40 \mathrm{~mL})$, and the solution was warmed and filtered over a Celite pad. Single crystals of $\mathbf{3}$ suitable for X-ray structural analysis were obtained by storing the solution overnight at room temperature. Yield: $0.38 \mathrm{~g}, 85 \%$. Mp: $299-301{ }^{\circ} \mathrm{C}$. ${ }^{1} \mathrm{H}$ NMR $(300 \mathrm{MHz}$, $\left.\mathrm{C}_{4} \mathrm{D}_{8} \mathrm{O}\right): \delta 7.44-7.09\left(\mathrm{~m}, 30 \mathrm{H}, \mathrm{C}_{6} H_{5}\right), 4.86(\mathrm{~s}, 2 \mathrm{H}, \mathrm{Si} H), 1.06(\mathrm{~s}$, $\left.36 \mathrm{H}, \mathrm{C}\left(\mathrm{CH}_{3}\right)_{3}\right)$ ppm. ${ }^{13} \mathrm{C} \mathrm{NMR}\left(75.47 \mathrm{MHz}, \mathrm{C}_{4} \mathrm{D}_{8} \mathrm{O}\right): \delta$ $169.81,143.46,142.30,137.11,132.60,130.50,130.17,128.81$, $128.25,128.12,127.95,127.50,126.99,54.58,32.01$ (br) ppm. ${ }^{29} \mathrm{Si}$ NMR $\left(59.63 \mathrm{MHz}, \mathrm{C}_{4} \mathrm{D}_{8} \mathrm{O}\right): \delta-96.65 \mathrm{ppm}(\mathrm{d}, J=286.18$ $\mathrm{Hz})$. EI-MS (70 eV) $m / z(\%): 728.4(100)\left[\mathrm{M}^{+}-\mathrm{N}=\mathrm{CPh}_{2}\right]$, 908.5(55) $[\mathrm{M}]^{+}, 454.2(30)[\mathrm{M} / 2]^{+}$. Anal. Calcd for $\mathrm{C}_{56} \mathrm{H}_{68} \mathrm{~N}_{8} \mathrm{Si}_{2}$ : C, 73.96; H, 7.54; N, 12.32. Found: C, 73.12; H, 8.07; N, 12.12 . Synthesis of 4 . A solution of $\mathrm{PhCH}=\mathrm{NPh}(0.18 \mathrm{~g}, 1 \mathrm{mmol})$ in toluene $(10 \mathrm{~mL})$ was added to a toluene solution $(35 \mathrm{~mL})$ of $\mathbf{1}$ $(0.29 \mathrm{~g}, 1 \mathrm{mmol})$ at $-30^{\circ} \mathrm{C}$. The reaction mixture was allowed to warm slowly to room temperature and stirred for an additional $1 \mathrm{~h}$ at the same temperature. After that all volatiles were removed under vacuum. The residue was dissolved in $n$-hexane $(40 \mathrm{~mL})$, and the solution was warmed and filtered over a Celite pad. The resulting solution was stored overnight at room temperature to afford colorless crystals of 4 . Yield: $0.42 \mathrm{~g}$, $88 \%$. Mp: $117{ }^{\circ} \mathrm{C}$. ${ }^{1} \mathrm{H}$ NMR $\left(\mathrm{C}_{6} \mathrm{D}_{6}, 500 \mathrm{MHz}\right): \delta 7.54-6.62$ $\left(\mathrm{m}, 15 \mathrm{H}, \mathrm{C}_{6} \mathrm{H}_{5}\right), 4.07(\mathrm{~s}, 1 \mathrm{H}, \mathrm{CH}), 1.15\left(\mathrm{~s}, 9 \mathrm{H}, \mathrm{C}\left(\mathrm{CH}_{3}\right)_{3}\right), 1.02(\mathrm{~s}$, $\left.9 \mathrm{H}, \mathrm{C}\left(\mathrm{CH}_{3}\right)_{3}\right) \mathrm{ppm} .{ }^{13} \mathrm{C} \mathrm{NMR}\left(125 \mathrm{MHz}, \mathrm{C}_{6} \mathrm{D}_{6}\right): \delta 174.16$, $159.97,150.66,145.71,131.26,131.22,130.15,129.34,129.22$, $129.11,128.81,128.75,128.24,126.02,124.89,124.22,121.27$, 118.36, 117.79, 54.65, 54.29, 53.28, 31.80, $30.47 \mathrm{ppm} .{ }^{29} \mathrm{Si}$ NMR $\left(\mathrm{C}_{6} \mathrm{D}_{6}, 59.62 \mathrm{MHz}\right): \delta-131.35 \mathrm{ppm}$. EI-MS $(70 \mathrm{eV}) \mathrm{m} / z(\%)$ : $475(100)[\mathrm{M}]^{+}$. Anal. Calcd for $\mathrm{C}_{28} \mathrm{H}_{34} \mathrm{ClN}_{3} \mathrm{Si}$ : C, 70.63; H, 7.20; N, 8.83. Found: C, 71.45; H, 7.49; N, 9.08.

X-ray Crystal Structure Determination. Suitable crystals of $\mathbf{2}$ and $\mathbf{4}$ were mounted on a glass fiber, and data was collected on 
an IPDS II Stoe image-plate diffractometer (graphite-monochromated Mo $\mathrm{K} \alpha$ radiation, $\lambda=0.71073 \AA$ ) at $133(2) \mathrm{K}$. The data for 3 were collected from a shock-cooled crystal at 100(2) K on a Bruker SMART 6000 diffractometer equipped with a rotating anode and INCOATEC mirror optics. The structures were solved by direct methods (SHELXS-97) ${ }^{30}$ and refined by full-matrix least-squares methods against $F^{2}$ (SHELXL-97). ${ }^{30}$ All non-hydrogen atoms were refined with anisotropic displacement parameters. The hydrogen atoms were refined isotropically at calculated positions using a riding model with their $U_{\text {iso }}$ values constrained to 1.5 times the $U_{\text {eq }}$ of their pivot atoms for terminal $\mathrm{sp}^{3}$-carbon atoms and 1.2 times for all other carbon atoms. Hydrogen atoms bound to nitrogen, silicon and the chiral carbon atoms of $\mathbf{4}$ were located and refined freely; for the latter only, unlike their location $U_{\text {iso }}$ was refined as being dependent on the pivot atoms.

Disordered moieties were refined using bond length restraints, rigid bond restraints, similarity restraints, and ADP restraints. Crystallographic data (excluding structure factors) for the structures reported in this paper have been deposited

(30) Sheldrick, G. M. Acta Crystallogr. Sect. A 2008, A64, 112-122. with the Cambridge crystallographic data center. Copies of the data can be obtained free of charge from the Cambridge crystallographic data center via www.ccdc.cam.ac.uk/data_request/ cif. Compound 2: Space group: $P \overline{1} ; a=8.2690(17) \AA, b=$ 9.7193(19) $\AA, c=17.875(4) \AA ; \alpha=101.04(3)^{\circ}, \beta=102.46(3)^{\circ}$, $\gamma=96.72(3)^{\circ}, R_{1}=0.0647$ for $[I>2 \sigma(I)], w R_{2}$ (all data) $=0.1500$ (CCDC number for 2: 778977). Compound 3: Space group: $P 2_{1} / n$;

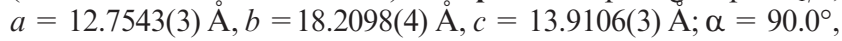
$\beta=113.1287(7)^{\circ}, \gamma=90.0^{\circ}, R_{1}=0.0367$ for $[I>2 \sigma(I)], w R_{2}$ (all data $)=0.0960($ CCDC number for $3: 781161)$. Compound 4: Space

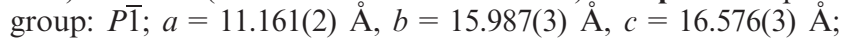
$\alpha=89.93(3)^{\circ}, \beta=83.27(3)^{\circ}, \gamma=71.19(6)^{\circ}, R_{1}=0.0873$ for $[I>2 \sigma(I)], w R_{2}$ (all data) $=0.1633(\mathrm{CCDC}$ number for 4 : 776751).

Acknowledgment. Support by the Deutsche Forschungsgemeinschaft is highly acknowledged.

Supporting Information Available: X-ray data for 2, 3, and 4 (CIF). This material is available free of charge via the Internet at http://pubs.acs.org. 